\title{
Prevalence of Obesity in mid adolescents in central India: a school based study
}

\author{
Sharma $\mathbf{R}^{1}$, Mandliya $\mathbf{J}^{2}$, Dhaneria $\mathbf{M}^{3}$, Tiwari $\mathbf{H}^{4}$ \\ ${ }^{1}$ Dr Roop Sharma, MBBS, MD, Fellow, Sir Ganga Ram Hospital, New Delhi, ${ }^{2}$ Dr Jagdish Mandliya, Associate \\ Professor*, ${ }^{3}$ Dr Mamta Dhaneria, Professor* ${ }^{4}$ Dr H.L Tiwari, Professor*. All are affiliated with Department of \\ Pediatrics, R D Gardi Medical College*, Ujjain, MP, India
}

Address for correspondence: Dr Roop Sharma, Email: roopksharma@gmail.com

\begin{abstract}
Introduction: Overweight and obesity among children and adolescents has increased significantly in the developed countries during the past two decades and similar trends are being observed even in the developing world. Methods: Mid adolescent boys and girls (14-16years) of three government and four private schools of Ujjain city were included with sample size of 1000. A pre designed questionnaire regarding nutritional and dietary history was prepared with measurement of anthropometry. Results: The overall prevalence of overweight and obese children in the present study was $6.8 \%$ and $3.7 \%$ respectively. The combined prevalence of overweight and obesity in the private and government schools was $12.2 \%$ and $8.4 \%$ respectively $(\mathrm{p}<0.05)$. Excess calorie intake was seen with $92.3 \%$ of obese children in government compared to $50.8 \%$ in private school $(\mathrm{p}=0.00)$. It was also found in our study that less outdoor activity, and spending more time with computer and TV was more common in overweight and obese children. Conclusion The combined prevalence of overweight and obesity was much higher in private schools than government school. BMI underestimates the obesity while WHR is the better indicator for early detection of central obesity in the adolescent age group. Various factors which were found to have correlation with overweight and obesity included calorie intake, number of meals per day, lack of physical activity and overindulgence in indoor activity in the present study.
\end{abstract}

Key words: Adolescent obesity, Body Mass Index , Waist Hip Ratio, Waist to Height Ratio.

\section{Introduction}

The World Health Organization (WHO) describes overweight and obesity as one of today's most important public health problems, which is escalating as a global epidemic [1]. It is also increasingly recognized as a significant problem in developing countries and countries undergoing economic transition [2]. The problem of overweight and obesity is confined not only to adults but also being reported among the children and adolescents of developed as well as developing countries. The prevalence of overweight and obesity among children and adolescents has increased significantly in the developed countries during the past two decades [3] and similar trends are being observed even in the developing world, though less rapidly [4-6].

This trend is of major concern, given the consequences that are associated with adolescent obesity both during Manuscript received: $9^{\text {th }}$ Mar 2014 Reviewed: $16^{\text {th }}$ Mar 2014 Author Corrected: $4^{\text {th }}$ Apr 2014
Accepted for Publication: 26 Apr 2014

adolescence [7] and adult life which include increased incidence of coronary artery diseases \& hypertension [8], diabetes, obstructive sleep apnea esophageal reflux \& gastric emptying disturbances, osteoarthritis \& flat feet, psychological dysfunction, self esteem \& social isolation [8], dyslipidemia and overall increase in morbidity and mortality in later life [9]. The most significant long-term consequences of childhood and adolescent obesity is its persistence into adulthood, with all the attendant health risks. There are evidences that children and adolescents of affluent families are increasingly becoming over-weight/obese in recent times, possibly because of decreased physical activity \& sedentary life styles [10] and change in dietary habits. Though several studies have been conducted from different parts of our country to evaluate the prevalence of obesity, very few studies have been done from central part of India. So we planned a school based
Available online at: www.ijmrr.in $51 \mid \mathrm{P}$ a g e 
observational study to detect the prevalence of obesity and hypertension among adolescents of Ujjain city.

\section{Materials and Methods}

Study subjects: School going mid adolescent boys and girls of age group 14-16 yrs from government and private schools of Ujjain city were included in study.

\section{Inclusion criteria.}

a. Age group 14-16 yrs.

b. The students and the school administration should give written consent.

\section{Exclusion criteria}

a. The students having systemic illnesses.

b. The students having congenital malformations.

3. Sample Size: 1000 students [ 466 from private \& 534 from government schools]

\section{Material used}

a. Weighing machine

b. Measuring tape (metallic)

c. Sphygmomanometer (Mercury)

\section{Method}

A pre designed questionnaire / proforma was prepared in order to adjust for the many of the possible confounders for the association with obesity among adolescents, all students of the study sample were subjected to a questionnaire and anthropometry was recorded.

\section{Sampling}

The current study was conducted in three government and four private schools of Ujjain city of Madhya
Pradesh. School was used as the main sampling unit task. Of all the schools in the region, three government and four private schools were randomly selected.

Children's parents or guardians were fully informed about the objectives and methods of the study and signed a consent form. The study protocol was approved by the Ethical committee of R.D Gardi Medical College and the school management

\section{Data collection}

Study period extended from October 2009 to June 2011. The data was collected on a predesigned proforma which included information regarding sociodemographic profile, life style, health behavior, anthropometric measurements.

\section{Anthropometrical measurements:}

a) Weight was measured using a spring balance with an accuracy of $\pm 50 \mathrm{~g}$. Subjects were weighed without shoes.

b) Height was also measured to the nearest $0.1 \mathrm{~cm}$ with the use of measurement scale put against the wall. Height was measured without shoes and with children keeping their shoulders in a relaxed position, their arms hanging freely and their head aligned in Frankfurt plane.

c) BMI was calculated by dividing weight $(\mathrm{kg})$ by height squared $\left(\mathrm{m}^{2}\right)$.

Formula:-Weight $(\mathrm{kg}) \div$ height $\left(\mathrm{m}^{2}\right)$.

Participants were classified as 'underweight', 'normal', 'overweight' and 'obese', according to the WHO age- and sex-specific BMI cutoff points [11].

\section{Results}

Table 1: Age and gender wise distribution of study subjects in government and private schools

\begin{tabular}{|c|c|c|c|c|c|c|c|c|}
\hline \multirow{2}{*}{$\begin{array}{l}\text { Age } \\
\text { (years) }\end{array}$} & \multicolumn{4}{|c|}{ Government } & \multicolumn{4}{|l|}{ Private } \\
\hline & BOYS(n) & $(\%)$ & GIRLS(n) & $(\%)$ & BOYS(n) & $(\%)$ & GIRLS(n) & $(\%)$ \\
\hline 14 & 103 & 37.87 & 57 & 29.38 & 97 & 33.00 & 85 & 35.42 \\
\hline 15 & 101 & 37.13 & 70 & 36.08 & 114 & 38.78 & 70 & 29.17 \\
\hline 16 & 68 & 25.00 & 67 & 34.54 & 83 & 28.23 & 85 & 35.42 \\
\hline Total & 272 & 100 & 194 & 100 & 294 & 100 & 240 & 100 \\
\hline
\end{tabular}

Table 1 shows distribution of boys and girls in government and private school. 
Table 2(a): Weight, Height \& BMI of 14yrs Group

\begin{tabular}{|l|l|l|l|l|l|}
\hline & Gov/ Pri & N & Mean & Std. Deviation & P value \\
\hline \multirow{3}{*}{ Weight } & Government & 160 & 41.8344 & 10.33552 & 0.001 \\
\cline { 2 - 6 } & Private & 182 & 45.3940 & 9.55415 & \\
\hline \multirow{3}{*}{ Height } & Government & 160 & 154.5231 & 9.44154 & 0.001 \\
\cline { 2 - 6 } & Private & 182 & 157.6687 & 7.14677 & \\
\hline \multirow{2}{*}{ BMI } & Government & 160 & 17.5410 & 3.16831 & 0.020 \\
\cline { 2 - 6 } & Private & 182 & 18.2797 & 2.85306 & \\
\hline
\end{tabular}

Above table shows that mean weight, height and BMI is higher in $14 \mathrm{yr}$ age group in private school than in government school with a significant $\mathrm{p}$ value according to independent $\mathrm{t}$ test.

Table 2(b): Weight, Height \& BMI of 15 yrs Group

\begin{tabular}{|l|l|l|l|l|l|}
\hline \multirow{3}{*}{ Weight } & Gove /Private & $\mathrm{N}$ & Mean & Std. Deviation & P value \\
& Government & 101 & 46.8525 & 9.52597 & \\
\cline { 2 - 6 } & Private & 114 & 47.9912 & 9.54928 & 0.383 \\
\hline \multirow{3}{*}{ Height } & Government & 101 & 164.7277 & 8.69756 & 0.000 \\
\cline { 2 - 6 } & Private & 114 & 159.8509 & 8.90732 & \\
\hline \multirow{2}{*}{ BMI } & Government & 101 & 17.2865 & 2.77587 & 0.000 \\
\cline { 2 - 6 } & Private & 114 & 18.9336 & 3.36827 & \\
\hline
\end{tabular}

Above table shows that mean weight and BMI is higher in private schools, whereas mean height is higher in government students in $15 \mathrm{yr}$ age group.

Table 2(c): Weight, Height \& BMI of 16yrs Group

\begin{tabular}{|l|l|l|l|l|l|}
\hline & Gov/ Pri & $\mathrm{n}$ & Mean & Std. Deviation & P value. \\
\hline \multirow{3}{*}{ Weight } & Government & 135 & 48.7556 & 11.62631 & \\
\cline { 2 - 6 } & Private & 168 & 46.9631 & 9.80547 & 0.14 \\
\hline \multirow{3}{*}{ Height } & Government & 135 & 160.6074 & 8.49064 & 0.002 \\
\cline { 2 - 6 } & Private & 168 & 157.1220 & 11.65362 & \\
\hline \multirow{2}{*}{ BMI } & government & 135 & 18.7517 & 3.74807 & 0.82 \\
\cline { 2 - 6 } & Private & 168 & 18.8386 & 3.10792 & \\
\hline
\end{tabular}

Above table shows that in this group mean height and weight is higher in students of government school than in private schools. P value is only significant for height.

Table 3: Prevalence of underweight, healthy, overweight and obese in the study group

\begin{tabular}{|c|c|c|c|c|c|c|c|c|}
\hline \multirow{2}{*}{$\begin{array}{l}\text { Classification of BMI } \\
\text { (Percentile) }\end{array}$} & \multicolumn{4}{|c|}{ Government } & \multicolumn{4}{|c|}{ Private } \\
\hline & $\begin{array}{c}\text { BOYS } \\
\text { n }\end{array}$ & $(\%)$ & $\begin{array}{c}\text { GIRLS } \\
\mathbf{n}\end{array}$ & $(\%)$ & $\begin{array}{c}\text { BOYS } \\
\text { n }\end{array}$ & $(\%)$ & $\begin{array}{c}\text { GIRLS } \\
\text { n }\end{array}$ & $(\%)$ \\
\hline Underweight $(<5)$ & 125 & 45.95 & 38 & 19.59 & 75 & 25.51 & 49 & 20.42 \\
\hline $\operatorname{Normal}\left(5-84^{\text {th }}\right)$ & 130 & 47.78 & 134 & 69.07 & 184 & 62.59 & 161 & 67.08 \\
\hline Overweight(85-94) & 4 & 1.47 & 18 & 9.28 & 25 & 8.50 & 21 & 8.75 \\
\hline Obese $(\geq 95)$ & 13 & 4.78 & 4 & 2.06 & 10 & 3.40 & 9 & 3.75 \\
\hline Total & 272 & 100 & 194 & 100 & 294 & 100 & 240 & 100 \\
\hline
\end{tabular}

Above table shows the higher number of overweight and obese children in private schools than in government school. (Significant $\mathrm{p}$ value $<0.05$ in chi square test) 
Table 4: Distribution of obesity among students according to body composition

\begin{tabular}{|c|c|c|c|c|c|c|c|c|c|c|}
\hline & & \multicolumn{4}{|c|}{ Government } & \multicolumn{4}{|c|}{ Private } & \multirow[t]{2}{*}{$P$ value } \\
\hline & & $\begin{array}{l}\text { BOYS } \\
\text { n }\end{array}$ & $(\%)$ & $\begin{array}{l}\text { GIRLS } \\
\text { n }\end{array}$ & $(\%)$ & $\begin{array}{l}\text { BOYS } \\
\text { n }\end{array}$ & $(\%)$ & $\begin{array}{l}\text { GIRLS } \\
\text { n }\end{array}$ & $(\%)$ & \\
\hline \multirow[t]{3}{*}{ WHR } & Non obese & 259 & 95.22 & 176 & 90.72 & 276 & 93.88 & 221 & 92.08 & \multirow[t]{3}{*}{0.04} \\
\hline & Obese & 13 & 4.78 & 18 & 9.28 & 18 & 6.12 & 19 & 7.92 & \\
\hline & Total & 272 & 100 & 194 & 100 & 294 & 100 & 240 & 100 & \\
\hline \multirow[t]{3}{*}{ WHtR } & Non obese & 259 & 95.20 & 180 & 92.80 & 276 & 93.90 & 226 & 94.20 & \multirow[t]{3}{*}{0.2} \\
\hline & Obese & 13 & 4.80 & 14 & 7.20 & 18 & 6.10 & 14 & 5.80 & \\
\hline & Total & 272 & 100.0 & 194 & 100.0 & 294 & 100.0 & 240 & 100.0 & \\
\hline
\end{tabular}

The above table shows prevalence of obesity is higher in girls of government school on the basis of WHR while it is more in boys in private schools.

Table 5: Prevalence of obesity in the study group in relation to health behavior

\begin{tabular}{|c|c|c|c|c|c|c|c|c|c|c|c|c|c|}
\hline \multirow{2}{*}{\multicolumn{2}{|c|}{ Health Behavior }} & \multicolumn{4}{|c|}{ Government } & \multirow[t]{2}{*}{$\begin{array}{c}P \\
\text { value }\end{array}$} & \multirow[t]{2}{*}{ OR } & \multicolumn{4}{|c|}{ Private } & \multirow[t]{2}{*}{$\begin{array}{c}P \\
\text { value. }\end{array}$} & \multirow[t]{2}{*}{ OR } \\
\hline & & $\begin{array}{c}\text { NO } \\
\text { n }\end{array}$ & $(\%)$ & $\begin{array}{c}\text { OB } \\
\mathrm{n}\end{array}$ & $(\%)$ & & & $\begin{array}{c}\text { NO } \\
\text { n }\end{array}$ & $(\%)$ & \begin{tabular}{c|} 
OB \\
$\mathbf{N}$
\end{tabular} & $(\%)$ & & \\
\hline \multirow[t]{3}{*}{$\begin{array}{l}\text { 1. Calorie } \\
\text { Intake }\end{array}$} & $\begin{array}{l}\text { Normal Or } \leq \\
\text { Normal }\end{array}$ & 184 & 43.1 & 3 & 7.7 & \multirow[t]{3}{*}{0.00} & \multirow[t]{3}{*}{0.06} & 106 & 22.6 & 32 & 49.2 & \multirow[t]{3}{*}{0.00} & \multirow[t]{3}{*}{0.28} \\
\hline & Excess Calorie & 243 & 56.9 & 36 & 92.3 & & & 363 & 77.4 & 33 & 50.8 & & \\
\hline & Total & 427 & 100 & 39 & 100 & & & 469 & 100 & 65 & 100 & & \\
\hline \multirow[t]{3}{*}{$\begin{array}{l}\text { 2. Number Of Meals } \\
\text { Per Day }\end{array}$} & $\begin{array}{l}\leq 4 \text { TIMES } \\
/ \text { DAY }\end{array}$ & 410 & 96.0 & 38 & 97.4 & \multirow[t]{3}{*}{0.66} & \multirow[t]{3}{*}{0.63} & 459 & 97.9 & 60 & 92.3 & \multirow[t]{3}{*}{0.01} & \multirow[t]{3}{*}{3.82} \\
\hline & $>4$ TIMES /DAY & 17 & 4.0 & 1 & 2.6 & & & 10 & 2.1 & 5 & 7.7 & & \\
\hline & TOTAL & 427 & 100.0 & 39 & 100 & & & 469 & 100 & 65 & 100 & & \\
\hline \multirow[t]{3}{*}{ 3. Smoking } & Yes & 1 & 0.2 & 0 & 0 & & & 2 & 0.4 & 0 & 0 & & \\
\hline & No & 426 & 99.8 & 39 & 100 & & & 467 & 99.6 & 65 & 100 & & \\
\hline & Total & 427 & 100.0 & 39 & 100 & & & 469 & 100 & 65 & 100 & & \\
\hline \multirow[t]{3}{*}{ 4. Diet } & Veg & 306 & 71.7 & 14 & 35.9 & \multirow[t]{3}{*}{0.00} & \multirow[t]{3}{*}{4.51} & 333 & 71.0 & 29 & 44.6 & \multirow[t]{3}{*}{0.00} & \multirow[t]{3}{*}{3.04} \\
\hline & Non Veg & 121 & 28.3 & 25 & 64.1 & & & 136 & 29.0 & 36 & 55.4 & & \\
\hline & Total & 427 & 100 & 39 & 100 & & & 469 & 100 & 65 & 100 & & \\
\hline \multirow[t]{3}{*}{ 5. Physical Activity } & $\leq 1 \mathrm{Hr} /$ Day & 222 & 52.0 & 21 & 53.8 & \multirow[t]{3}{*}{0.82} & \multirow[t]{3}{*}{0.48} & 166 & 35.4 & 37 & 56.9 & \multirow[t]{3}{*}{0.00} & \multirow[t]{3}{*}{0.5} \\
\hline & $>1 \mathrm{Hr} /$ Day & 205 & 48.0 & 18 & 46.2 & & & 303 & 64.6 & 28 & 43.1 & & \\
\hline & Total & 427 & 100 & 39 & 100 & & & 469 & 100 & 65 & 100 & & \\
\hline \multirow[t]{3}{*}{ 6. TV /Comp } & $\leq 2 \mathrm{Hr} /$ Day & 93 & 21.8 & 13 & 33.3 & \multirow[t]{3}{*}{0.09} & \multirow[t]{3}{*}{1.79} & 83 & 17.7 & 18 & 27.7 & \multirow[t]{3}{*}{0.03} & 1.80 \\
\hline & $>2 \mathrm{Hr} /$ Day & 334 & 78.2 & 26 & 66.7 & & & 386 & 82.3 & 47 & 72.3 & & \\
\hline & Total & 427 & 100 & 39 & 100 & & & 469 & 100 & 65 & 100 & & \\
\hline
\end{tabular}

Above table shows correlation of obesity in relation to health behavior in government and private schools.

\section{Discussion}

Our study was conducted in Ujjain city to compare prevalence of obesity as well hypertension among adolescent children aged 14-16 years (Mid. 
Adolescents) of $8^{\text {th }}$ to $10^{\text {th }}$ class of 3 government and 4 private schools. Various factors were taken into account to understand their effect on obesity and hypertension in adolescent children.

The various factors which were studied in the present study were - calorie intake, number of meals, type of food whether vegetarian or non vegetarian, duration of outdoor physical activity, time spent in watching TV or playing computer games. Other factors like family history of obesity among one or both parents were also taken into consideration. There were total 272 boys and 194 girls in the age group of 14-16 years in government school as opposed to 294 boys and 240 girls in private school. Over all distribution of over-weight and obesity in government schools is $4.7 \%$ and $3.6 \%$. Over all prevalence of over-weight and obesity in private school is $8.6 \%$ and $3.8 \%$. The prevalence of obesity is higher in private as compared to government $3.78 \%>3.50 \%$ which was similar to study of $M$ Premnath et al [12] $(3.1 \%>2.6 \%)$. Present study reveals $86.2 \%$ of males , $53.8 \%$ females of private schools were overweight v/s $13.8 \%$ males and $46.2 \%$ females of government schools which was statistically highly significant $(p=0.00)$ similar observations were found by $M$ Premnath et al [12]. The prevalence of obesity in girls is higher than boys $(3.75 \%>3.40 \%)$ in our study. Reason behind this high number of obese and overweight children was abnormal dietary pattern, non vegetarian diet, high number of meals, less outdoor activities, high number of hours of viewing TV. These differences were more in children of private schools as compared to government schools.

When WHR was studied in the study group boys of private schools were found to be more obese as compared to government boys $(6.12 \%>4.78 \%)$ and prevalence of obese girls of government were more as compared to private schools $(9.28 \%>7.92 \%)$, which was statistically significant $\mathrm{p}=0.04$ according to $\chi^{2}$ test. Hence the overall girls of both government and private schools are showing significantly higher prevalence of central obesity than boys $(3.7 \%>3.1 \%)$ similar to the findings of Moustafa et al [13] where $31.9 \%$ girls and $0.3 \%$ boys were obese.

According to waist height ratio $4.80 \%$ boys and $7.20 \%$ of girls $(\mathrm{p}<0.05)$ were obese in government schools while $6.10 \%$ boys and $5.80 \%$ girls were obese in private school which was more or less same. It was not found to be statistically significant. Similar findings were observed by Moustafa et al [13] (18.5\%>14.8\%) but the prevalence was higher in his study. The prevalence is higher in this study as the number of cases was higher $(n=1500)$ and the age group was between 1119 years.

Among 39 obese children in government school $21(53.8 \%)$ were having outdoor physical activity $\leq$ $1 \mathrm{hr} /$ day where as in private school it was $37(56.9 \%)$ students $(\mathrm{p}=0.00)$. Similar observations were found by $\mathbf{J}$ prajapati et al [14], WHO [15] .So sedentary habits and not playing outdoor games or cycling is closely related to obesity. Similarly out of 39 obese children of government school $66.7 \%$ students were watching TV /computer for $>2$ hours/day as opposed to $72.3 \%$ students among private schools $(\mathrm{p}=0.00$ statistically highly significant by $\chi^{2}$ test). Our study findings are similar to the findings of Joyce et al [6]. Indoor activities like watching TV and computer is closely associated with obesity (Table 5).

125 boys and 38 girls from government schools were found to be underweight comparable to 75 boys and 49 girls from private schools.

\section{Conclusion}

1. This study concludes with overall prevalence of overweight and obese children in our study is $6.8 \%$ and $3.7 \%$ respectively with overall prevalence of over-weight was higher in girls than boys $(3.9 \%>2.9 \%)$.

2. The prevalence of obesity in boys was higher in government as compared to private $(4.78 \%>3.40 \%)$. Whereas girls were more obese in private as compared to government $(3.75 \%>2.06)$ and is statistically significant.

3. Combined prevalence of overweight and obesity in the private and government schools was $12.2 \%$ and $8.4 \%$ respectively

4. BMI underestimates the obesity. WHR is the better indicator for early detection of central obesity in the adolescent age group.

5. The various factors which were studied had correlation with prevalence of obesity and hypertension were:

a. Taking more calories per day.

b. Consuming more fatty diet (non vegetarian).

c. Less outdoor physical activity.

d. Spending $>2$ hours per day in front of $\mathrm{TV}$ and computers were more at risk of getting overweight and obese.

\section{Funding: Nil}

Conflict of interest: Nil

Available online at: www.ijmrr.in 55 | P a g e 


\section{References}

1. WHO report on Childhood overweight and obesity. Available at: http://www.who.int/dietphysicalactivity/childhood/en/ cited on $26^{\text {th }}$ September 2014.

2. Popkin BM. The nutrition transition and obesity in the developing world. J Nutr. 2001 Mar;131(3):871S873S..

3. Chinn S, Rona RJ. Prevalence and trends in overweight and obesity in three cross-sectional studies of British children. BMJ. 2001 Jan 6;322(7277):24-6.

4. de la Eva RC, Baur LA, Donaghue KC, Waters KA. Metabolic correlates in obstructive sleep apnoea. J Pediatr. 2002 Jun;140(6):654-9.

5. Apter D, Butzow T, Laughlin GA, Yen SS. Metabolic features of polycystic ovary syndrome are found in adolescent girls with hyperandrogenism. J Clin Endocrinol Metab. 1995 Oct;80(10):2966-73..

6. Giammattei J, Blix G, Marshak HH, Wollitzer AO, Pettitt DJ. Television watching and soft drink consumption: Associations with obesity in 11-13 yr old children. Arch Pediatr Adolesc Med. 2003 Sep;157(9):882-6.

7. Must A, Strauss RS. Risks and consequences of childhood and adolescent obesity. Int J Obes Relat Metab Disord. 1999 Mar;23 Suppl 2:S2-11.

8. Gunell DJ, Frankel SJ, Nachahal K, Peters TJ, Smith GD. Childhood obesity and adult cardiovascular mortality: a 57-y follow-up study based on the Boyd Orr cohort. Am J Clin Nutr. 1998 Jun;67(6):1111-8.

9. THEODORE B. VAN ITALLIE. Health implications of overweight and obesity in the US population: Ann Intern Med. 1985;103(6_Part_2):983-988. doi:10.7326/0003-4819-103-6-983.

10. William H. Dietz Jr, Steven L, Gortmaker . Do we fatten our children at the television set, Obesity and television viewing in children and adolescents. Pediatrics. 1985 May;75(5):807-12.

11. World Health Organization Expert Committee. Physical status, the use and interpretation of anthropometry: WHO Technical Report Series No. 854. Geneva: WHO, 1995.

12. Premanath M, Basavanagowdappa H, Shekar MA, Vikram SB, Narayanappa D. Mysore childhood obesity study: Indian Pediatr. 2010; 47(2): 171-173.

13. Abolfotouh MA, Sallam SA, Mohammed MS, Loutfy AA, Hasab AA. Prevalence of elevated blood pressure and association with obesity in egyptian school adolescents. Int J Hypertens. 2011 Mar 8;2011:952537. doi: $10.4061 / 2011 / 952537$.

14. Prajapati J, Oza J, Prajapati P, Bhagyalaxmi A, Rawal V.S : Prevalence of behavioral risk factors of cardiovascular disease among school going adolescents of Ahmedabad, Gujarat: Health and population : Perspectives and issues. 2009; 32(4): 198-203.

15. Obesity: Preventing and Managing the Global epidemic, Report of WHO Consultation. World Health Organ Tech Rep Ser. 2000;894:i-xii, 1-253.

\section{How to cite this article?}

Sharma R, Mandliya J, Dhaneria M, Tiwari H L. Prevalence of Obesity in mid adolescents in central India: a school based study. Int J Med Res Rev 2015;3(1):51-56. doi: 10.17511/ijmrr.2015.i1.09 